\title{
Immunomodulatory activity of extracts from Cordia superba Cham. and Cordia rufescens A. DC. (Boraginaceae), plant species native from Brazilian Semi-arid
}

\author{
José Fernando Oliveira Costa, ${ }^{1}$ Juceni P. L. David, ${ }^{2}$ Jorge M. David, ${ }^{3}$ Ana M. Giulietti, ${ }^{4}$ \\ Luciano P. Queiroz, ${ }^{4}$ Ricardo R. Santos, ${ }^{1}$ Milena Botelho P. Soares $*, 1$
}

${ }^{1}$ Laboratório de Engenharia Tecidual e Imunofarmacologia, Centro de Pesquisas Gonçalo Moniz, FIOCRUZ/BA, Rua Waldemar Falcão, 121, 40296-750 Salvador-BA, Brazil,

${ }^{2}$ Departamento do Medicamento, Faculdade de Farmácia, Universidade Federal da Bahia, 40170-280 Salvador-BA, Brazil,

${ }^{3}$ Departamento de Química Orgânica, Instituto de Química, Universidade Federal da Bahia, 40170-280 Salvador-BA, Brazi,

${ }^{4}$ Departamento de Ciências Biológicas, Universidade Estadual de Feira de Santana, 44031-060 Feira de Santana-BA, Brazil

\begin{abstract}
RESUMO: "Atividade imunomoduladora de extratos de Cordia superba Cham. and Cordia rufescens A. DC. (Boraginaceae), espécies de plantas nativas do semi-árido brasileiro". A família Boraginaceae é amplamente distribuída no Brasil e na região nordeste algumas espécies são usadas popularmente no tratamento de reumatismo, dores menstruais e dispepsias. Neste trabalho foram estudadas as espécies Cordia superba Cham. and C. rufescens A. DC., nativas da região semi-árida brasileira, objetivando investigar a atividade imunomoduladora. Seis extratos foram preparados a partir de partes aéreas das espécies. A citotoxicidade foi avaliada usando culturas de esplenócitos de camundongos BALB/c. A atividade imunomoduladora foi determinada por ensaios in vitro usando macrófagos e linfócitos murinos ativados. Macrófagos peritoneais obtidos de camundongos BALB/c foram estimulados com IFN- $\gamma$ and LPS na presença/ ausência das amostras. A produção de NO foi medida indiretamente através do método de Griess. Três amostras inibiram a produção de NO em valores próximos a $50 \%(100 \mu \mathrm{g} / \mathrm{mL})$. Os efeitos das amostras sobre os linfócitos foram avaliados cultivando esplenócitos de camundongos BALB/c em presença destas amostras e de concanavalina A. A proliferação foi determinada pela análise da incorporação de ${ }^{3} \mathrm{H}$-tritiada. Amostras de duas espécies apresentaram uma forte atividade inibidora sobre a proliferação de linfócitos e sobre a produção de IL-2. Dois extratos clorofórmicos (partes aéreas de C. rufescens) tiveram os menores valores de $\mathrm{IC}_{50}(7,6$ and 11,0 $\mu \mathrm{g} / \mathrm{mL})$.
\end{abstract}

Unitermos: Cordia, Boraginaceae, atividade imunomoduladora.

\begin{abstract}
The family Boraginaceae is widely distributed in Brazil and in the Northeastern region some species are popularly used to treat symptoms of rheumatism, painful menstruation and dyspepsia. In this work we studied Cordia superba Cham. and C. rufescens A. DC., native from Brazilian Semi-arid region, in order to investigate their immunomodulatory activity. Six extracts were prepared from aerial parts of $C$. superba and $C$. rufescens. The cytotoxicity was evaluated using splenocytes from BALB/c mice. The immunomodulatory activity was determined by in vitro assays using activated mouse macrophages and lymphocytes. Peritoneal macrophages obtained from BALB/c mice were stimulated with IFN- $\gamma$ and LPS in the presence/absence of the samples. The NO production was measured indirectly through Griess method. Three samples inhibited the production of nitric oxide in values near $50 \%$ at a concentration of $100 \mu \mathrm{g} / \mathrm{mL}$. To evaluate the effects of the extracts on lymphocytes, splenocytes from BALB/c mice were incubated with the samples and concanavalin A. Proliferation inhibition was determined by analysis of ${ }^{3} \mathrm{H}$-thymidine uptake. Samples from the two species had a strong inhibitory activity on lymphocyte proliferation and IL-2 production. Two chloroform extracts prepared from aerial parts of $C$. rufescens had the lowest $\mathrm{IC}_{50}$ values $(7.6$ and $11.0 \mu \mathrm{g} / \mathrm{mL}$ ).
\end{abstract}

Keywords: Cordia, Boraginaceae, immunomodulatory activity. 


\section{INTRODUCTION}

The family Boraginaceae comprises about 2740 species and 148 genera distributed in temperate and tropical zones of Europe, Asia, Africa, Australia, and Americas (Langstrom and Chase, 2002). Cordia, with more than 200 species, is one of the largest genera (Gottschling et al., 2005). It was recorded 46 species of Boraginaceae in the Brazilian semi-arid, 26 belonging to Cordia (Stapf, 2006).

Species of Cordia are largely employed in folk medicine worldwide. In Northeastern Brazil these plants are used to treat symptoms of rheumatism, painful menstruation and dyspepsia (Silva et al., 2004; Agra et al., 2007; Biavatti et al., 2007). Cordia rufescens is a shrub popularly known in the same region as "ramelade-velho" and along with other species from genus Cordia is used in popular medicine as abortive, antiinflammatory and to treat dysmenorrhea (Silva et al., 2004).

Immunopathologies such as autoimmune and allergic processes are diseases with high incidence and to which the currently available drugs, although efficient in most cases, cause undesirable side effects, resulting in complications to patients, especially after long term use. The search for new bioactive molecules in plants is of great interest, considering the diversity of chemical entities produced by them (Gottlieb et al., 1996) and the need of new medicines for more effective treatment of pathologies with lower toxic effects. In this report we evaluated the immunomodulatory activity of C. rufescens and C. superba extracts on inhibition of lymphoproliferation and nitric oxide production.

\section{MATERIAL AND METHODS}

\section{Preparation of extracts}

Plant specimens were collected in semiarid areas of the Bahia State, Brazil (Table 1) in authorized areas by IBAMA (Brazilian Institute for the Environment and Natural Resources), dried at $40{ }^{\circ} \mathrm{C}$ and received botanic identity. Vouchers were prepared and stored at the Universidade Estadual de Feira de Santana Herbarium (HUEFS). Material from one individual of C. superba and from two individuals of C. rufescens were studied. Dried stem and leaves of $C$. superba $(200$ and $90 \mathrm{~g}$, respectively) and C. rufescens (183 and 235 $\mathrm{g}$ of stems; 100 and $57 \mathrm{~g}$ of leaves) were individually extracted with $\mathrm{MeOH}$. Thus, $1.32 \mathrm{~g}(0.66 \%)$ of $\mathrm{MeOH}$ extract was obtained from $200 \mathrm{~g}$ of stem and $10.5 \mathrm{~g}$ (11.67\%) from $90 \mathrm{~g}$ of leaves of C. superba. Also, 891 $\mathrm{mg}(0.49 \%)$ and $8.5 \mathrm{~g}(8.5 \%)$ of $\mathrm{MeOH}$ extract were obtained from $183 \mathrm{~g}$ and $100 \mathrm{~g}$ of stems and $6.1 \mathrm{~g}(2.6 \%)$ and $6.0 \mathrm{~g}(10.53 \%)$ from $235 \mathrm{~g}$ and $57 \mathrm{~g}$ of leaves of C. rufescens specimens. Separately, the crude extracts obtained were partitioned with $\mathrm{CHCl}_{3} / \mathrm{MeOH}: \mathrm{H}_{2} \mathrm{O}$
(6:4). These procedures allowed the production of 538.2 $\mathrm{mg}(40.8 \%)$ and $7.4 \mathrm{~g}(70.5 \%)$ of $\mathrm{CHCl}_{3}$ extract from C. superba (stem and leaves) and $83.2 \mathrm{mg}(9.3 \%)$ and $1.8 \mathrm{~g}(21.1 \%)$ of one sample and $108.7 \mathrm{mg}(1.8 \%)$ and $1.2 \mathrm{~g}(20 \%)$ from the other sample of C. rufescens. The hydroalcoholic fraction, after the evaporation of $\mathrm{MeOH}$ under vacuum, gave rise to the aqueous phases and was further partitioned with EtOAc: $\mathrm{H}_{2} \mathrm{O}$. In the latter procedure $121.4 \mathrm{mg}(9.2 \%)$ and $838.5 \mathrm{mg}(8 \%)$ of $C$. superba were obtained (stem and leaves, respectively) and $215.3 \mathrm{mg}(24.2 \%)$ and $2.2 \mathrm{~g}(25.9 \%)$ of C. rufescens and $82 \mathrm{mg}(1.34 \%)$ and $138.0 \mathrm{mg}(2.3 \%)$ from the other sample of the same specie. The final extracts were dissolved using dimethyl sulfoxide (Sigma, St. Louis, MO) adjusting a final concentration for $10 \mathrm{mg} / \mathrm{mL}$. The samples were sterilized with $60,000 \mathrm{rad}$ of gamma radiation (CIS International IBL437C, France) for use in biological assays.

\section{Cytotoxicity assay}

To determine the cytotoxicity of the samples, splenocytes from BALB/c mice $\left(6 \times 10^{5}\right.$ cells/well) were cultured in 96 well plate in Dulbecco's Modified Eagle's Medium (DMEM, Sigma Chemical Co., St. Louis, MO) supplemented with $10 \%$ fetal calf serum (Cultilab, Campinas, SP, Brazil) and $50 \mu \mathrm{g} / \mathrm{mL}$ of gentamycin (Novafarma, Anápolis, GO, Brazil). Each extract was evaluated in five concentrations starting at $100 \mu \mathrm{g} / \mathrm{mL}$, in triplicates. Cells were incubated in the presence of $1 \mu \mathrm{Ci}$ / well $\left[\right.$ methyl $\left.-{ }^{3} \mathrm{H}\right]$ thymidine (Amersham, Little Chalfont, England) during $24 \mathrm{~h}$ at $37{ }^{\circ} \mathrm{C}$ and $5 \% \mathrm{CO}_{2}$. After this period, cultures were harvested using a cell harvester (Filtermate 196, Packard, Groningen, Netherlands) to determine the ${ }^{3} \mathrm{H}$-thymidine incorporation using a beta radiation counter ( $\beta$-matrix 9600, Packard, Groningen, Netherlands). The viability of the cells was determined by the thymidine incorporation and the cytotoxicity was calculated in relation to the ${ }^{3} \mathrm{H}$-thymidine incorporation of untreated cultures.

\section{Nitric oxide assay}

Peritoneal exudate cells were obtained by washing the peritoneal cavity of mice with cold Hank's balanced salt solution (HBSS; Life Technologies, GIBCO-BRL, Gaithersburg, MD) five days after injection of $3 \%$ thioglycollate in saline $(1.5 \mathrm{~mL}$ per mouse). Peritoneal cells were washed twice with HBSS and re-suspended in RPMI medium (GIBCO-BRL) supplemented with $10 \%$ fetal calf serum (Cultilab, Campinas, SP, Brazil), L-glutamine (2 mM), RPMI 1640 vitamins solution (1\%) (Sigma), sodium pyruvate $(1 \mathrm{mM})$, HEPES $(10 \mathrm{mM}), 2$-mercaptoethanol $(50 \mu \mathrm{M})$, and gentamycin $(50 \mu \mathrm{g} / \mathrm{mL})$ (Sigma, St. Louis, MO). Cells were plated $\left(2 \times 10^{5}\right.$ cells/well) in 96 well plates. After one hour of incubation at $37^{\circ} \mathrm{C}$, non-adherent cells 
Table 1. Voucher of the sampled species of Cordia.

\begin{tabular}{l|lllll}
\hline Sample & \multicolumn{1}{|c}{ Species } & \multicolumn{1}{c}{ Local of collect } & \multicolumn{1}{c}{ Solvent used } & \multicolumn{1}{c}{ Plant part } & \multicolumn{1}{c}{ Voucher } \\
\hline CS1 & C. superba Cham. & Rio de Contas/BA & Chloroform & Stem & A.M.Giulietti 2023 (HUEFS 59810) \\
CS2 & C. superba Cham. & Rio de Contas/BA & Ethyl acetate & Stem & A.M.Giulietti 2023 (HUEFS 59810) \\
& C. rufescens A. DC. & Sento Sé/BA & Chloroform & Aerial parts* & K.R.B.Leite et al. 155 (HUEFS 59982) \\
CR2 & C. rufescens A. DC. & Sento Sé/BA & Ethyl acetate & Aerial parts & K.R.B.Leite et al. 155 (HUEFS 59982) \\
CR3 & C. rufescens A. DC. & Morro do Chapéu/BA & Chloroform & Aerial parts & C. Correia et al. 93 (HUEFS 59087) \\
CR4 & C. rufescens A. DC. & Morro do Chapéu/BA & Ethyl acetate & Aerial parts & C. Correia et al. 93 (HUEFS 59087) \\
\hline
\end{tabular}

* Branches and leaves

were removed by washing with complete RPMI. Cultures were then stimulated with $1 \mu \mathrm{g} / \mathrm{mL}$ lipopolysaccaride (LPS from Escherichia coli serotype 0111:B4, Sigma) in combination with $5 \mathrm{ng} / \mathrm{mL}$ interferon- $\gamma$ (IFN- $\gamma$; PharMingem, S. Diego, CA) and treated with various concentrations of extracts, as described in figure legends, in a final volume of $200 \mu \mathrm{L}$. Cell-free supernatants were collected at $24 \mathrm{~h}$ of culture for determination of nitrite concentration using the Griess method, as described previously (Ding et al., 1988).

\section{Lymphoproliferation assay}

BALB/c splenocytes suspension were prepared in complete RPMI medium and cultured in 96 well plates at $6 \times 10^{5}$ cells/well in $200 \mu \mathrm{L}$, in triplicates, in the presence of concanavalin A (Con A; $2 \mu \mathrm{g} / \mathrm{mL}$ ), alone or various concentrations of plant extracts, as described in figure legends. After $48 \mathrm{~h}$, plates were pulsed with 1 $\mu \mathrm{Ci}$ of $\left[\right.$ methyl $\left.-{ }^{3} \mathrm{H}\right]$ thymidine for $12 \mathrm{~h}$, and proliferation was assessed by measurement of ${ }^{3} \mathrm{H}$-thymidine uptake. The percentage of inhibition of lymphocyte proliferation by the extracts was determined in relation to untreated controls.

\section{Myxed lymphocyte reaction (MRL)}

$\mathrm{BALB} / \mathrm{c}\left(\mathrm{H}-2^{\mathrm{d}}\right)$ mice were weekly immunized with C57BL/6 (H-2 $\left.{ }^{\mathrm{b}}\right)$ splenocytes intraperitoneally $\left(10^{7}\right.$ cells/mouse). After 3 weeks of immunization, mice were sacrificed for spleen cell preparation in DMEM medium supplemented as described above. Spleen cells were cultured in 96 well plates at $5 \times 10^{5}$ cells/well in the absence or in the presence of irradiated C57BL/6

Table 2. LC50 and EC50 of samples tested.

\begin{tabular}{l|c|c|c}
\hline Sample & $\begin{array}{c}\mathrm{LC}_{50} \\
(\mu \mathrm{g} / \mathrm{mL})\end{array}$ & $\begin{array}{c}\mathrm{EC}_{50} \\
\text { lymphoproliferation } \\
(\mu \mathrm{g} / \mathrm{mL})\end{array}$ & $\begin{array}{c}\mathrm{EC}_{50} \text { Myxed } \\
\text { lymphocyte } \\
\text { reaction } \\
(\mu \mathrm{g} / \mathrm{mL})\end{array}$ \\
\hline $\mathrm{CS} 1$ & $\mathrm{NC}$ & 21.6 & 20.7 \\
$\mathrm{CS} 2$ & $\mathrm{NC}$ & 36.9 & 13.6 \\
$\mathrm{CR} 1$ & 34.2 & 7.6 & 6.0 \\
$\mathrm{CR} 2$ & $\mathrm{NC}$ & 40.3 & 15.5 \\
$\mathrm{CR} 3$ & 32.8 & 11.0 & 7.9 \\
$\mathrm{CR} 4$ & $\mathrm{NC}$ & 36.9 & 8.8 \\
\hline
\end{tabular}

$\mathrm{NC}=$ not calculated splenocytes at $10^{6}$ cells/well (dose of $3000 \mathrm{rad}$ ) and extracts, in triplicates. After $72 \mathrm{~h}$ of culture, plates were pulsed with ${ }^{3} \mathrm{H}$-thymidine for $12 \mathrm{~h}$ for proliferation assessment, as described above.

\section{$\mathrm{EC}_{50}$ and $\mathrm{LC}_{50}$ calculations and statistical analyses}

The lethal concentration for $50 \%$ of cells $\left(\mathrm{LC}_{50}\right)$, the effective concentrations for $50 \%\left(\mathrm{EC}_{50}\right)$ of lymphoproliferation and MLR were calculated based in a nonlinear regression (curve fit). The statistical analyses were made by one-way ANOVA with Dunnett's post test using Graph Pad Prism version 4.0 (Graph Pad Software, San Diego, CA, USA). Differences were considered significant when $\mathrm{p}$ values were $<0.05$.

\section{RESULTS}

\section{Samples and cytotoxicity values}

Two species of the genus Cordia were analyzed, C. superba and C. rufescens. The extracts were obtained using chloroform and ethyl acetate as solvents. Six different extracts were analyzed in different concentrations. Stem and aerial parts of the plants were used and, from C. rufescens, two collects were done in different localities, generating two extracts of the same part and with the same solvent (Table 1). Samples were assayed in five different concentrations, starting at 100 $\mu \mathrm{g} / \mathrm{mL}$. As shown in Table 2, the lethal concentration for $50 \%\left(\mathrm{LC}_{50}\right)$ could be determined only for two samples, CR1 and CR3 obtained from C. rufescens (34.2 and 32.8 $\mu \mathrm{g} / \mathrm{mL}$, respectively) The other four samples did not present cytotoxicity to allow the calculation the $\mathrm{LC}_{50}$. The cytotoxicity of the samples is shown in Figure 1a.

\section{Immunomodulatory activity assays}

First we tested the activity of the extracts on cultures of activated macrophages. The samples tested did not have a high inhibitory activity on the nitric oxide production. The maximum inhibition was achieved with CS1, CR1 and CR3, which had, respectively, 54.8, 52.9 and $44.9 \%$ when assayed at $100 \mu \mathrm{g} / \mathrm{mL}$ (Figure $1 \mathrm{~b} ; p<$ $0.05)$.

The extracts had strong inhibitory activity in lymphocyte cultures, CR1 and CR3 have the lowest 
1a

Cytotoxicity

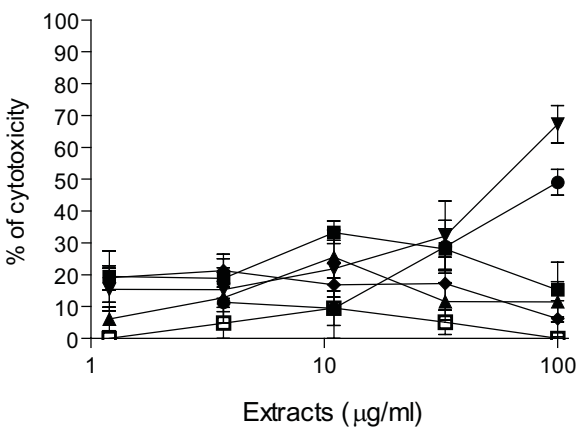

1c Lymphoproliferation

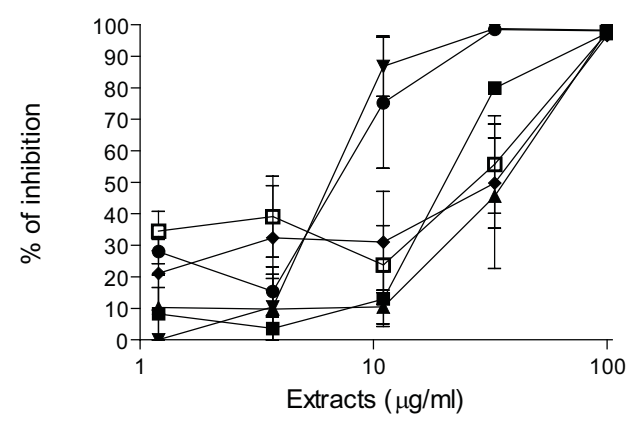

$1 b$

Nitric oxide production

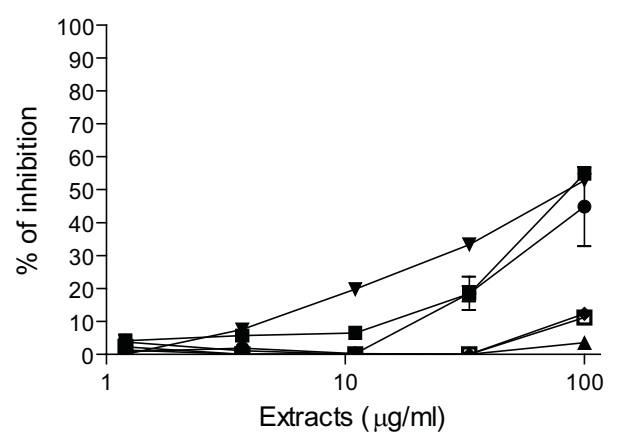

1d

Mixed lymphocyte reaction

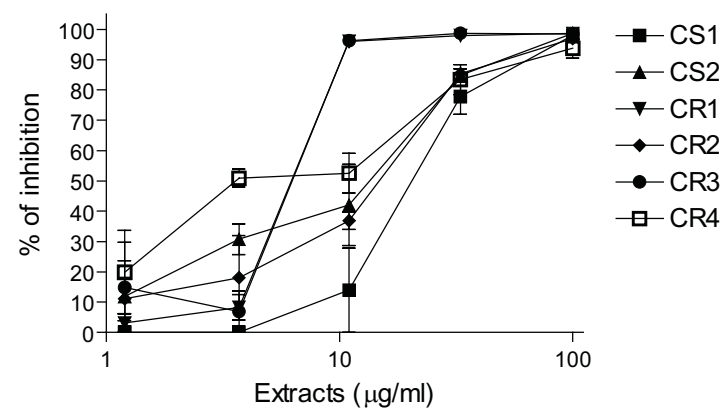

Figure 1. Cytotoxicity and immunomodulatory activity of extracts obtained from two species of Cordia. (1a) Mouse splenocytes (6 x 105 cells/well) were cultured during $24 \mathrm{~h}$ in DMEM, in presence or absence of extracts and $3 \mathrm{H}$-thymidine to determine the cytotoxicity. (1b) Mouse macrophages obtained from peritoneal exudate were stimulated with IFN- $\gamma$ and LPS and cultivated in presence or absence of the samples. The nitric oxide production was estimated through nitrite dosage by Griess method. The inhibition of lymphoproliferation was determined by culturing splenocytes from naïve mice during $48 \mathrm{~h}$ with Con A (1c) or BALB/c $(\mathrm{H}-2 \mathrm{~d})$ splenocytes with $\mathrm{C} 57 \mathrm{BL} / 6(\mathrm{H}-2 \mathrm{~b})$ irradiated splenocytes for $72 \mathrm{~h}(1 \mathrm{~d})$, in triplicates, as described in Materials and methods. Proliferation was measured by ${ }^{3} \mathrm{H}$-thymidine incorporation. Data represent the mean \pm SD 2-4 independent experiments.

$\mathrm{EC}_{50}$ values for proliferation inhibition of lymphocytes stimulated with concanavalin A (Table 2). These samples had high inhibitory activity even when assayed at concentrations below $100 \mu \mathrm{g} / \mathrm{mL}$. CR2 and CR4, samples extracted from the same specie (C. rufescens) but using different parts of the specimen, had higher values of $\mathrm{EC}_{50}$. CS1 and CS2, extracts from C. superba, presented values of inhibition up to $70 \%$ (Figure 1c). All the samples inhibited IL-2 production higher than $50 \%$ when assayed at $100 \mu \mathrm{g} / \mathrm{mL}$, being CR2 and CR4 the most potent samples ( 80.7 and $84.8 \%$, respectively; $p<0.05)$.

Similar results were obtained in cell cultures of mixed lymphocyte reaction (MLR). CR1 and CR3 had also a low $\mathrm{EC}_{50}$ values $(6.0$ and $7.9 \mu \mathrm{g} / \mathrm{mL})$ in this assay. In addition, CR4 had the third lowest $\mathrm{EC}_{50}(8.8 \mu \mathrm{g} /$ $\mathrm{mL}$ ) in MLR assay (Table 2). All samples inhibited the proliferation in MLR in percentuals above $90 \%$, when assayed at $100 \mu \mathrm{g} / \mathrm{mL}$ (Figure $1 \mathrm{~d}$ ).

\section{DISCUSSION}

A great variety of uses in ethnopharmacology for species of Cordia sp. has been reported (Ficarra et al., 1995; Reddy et al., 2002; Agra et al., 2007). C. globosa and $C$. verbenacea have been used in the folk medicine for treatment of rheumatism, painful menstruation and gastric ulcer (Reddy et al., 2002; Al-Awadi, 2001). Some pharmacologically active metabolites with analgesic, antiinflammatory, antiarthritic and larvicidal activities were already purified from Cordia sp., emphasizing an immunomodulatory activity of this genus (Sertié et al., 1991; Silva et al., 2003; Arrebola et al., 2004; Santiago et al., 2005). The species Cordia superba Cham. and Cordia rufescens A. DC (Boraginaceae), endemic in the Brazilian semi-arid, were investigated for the first time regarding their biological activities.

In general the samples had low cytotoxicity. Only two samples had their $\mathrm{LC}_{50}$ calculated (Table 2). The others could not be determined because the results obtained did not permit the calculation of the lethal doses, indicating that $\mathrm{LC}_{50}$ values for these samples 
are superior to $100 \mu \mathrm{g} / \mathrm{mL}$. It is interesting to note that $\mathrm{LC}_{50}$ values of CR1 and CR3 extracts are similar (Table 2). The samples were extracted from the same specie, prepared with aerial parts of different specimens, collected in different localities (Sento Sé and Morro do Chapéu) and the same solvent was used (Table 1).

Three samples (CS1, CR1 and CR3) inhibited NO production next to $50 \%$ when assayed at $100 \mu \mathrm{g} / \mathrm{mL}$. However, CR1 and CR3 had high cytotoxicity at 100 $\mu \mathrm{g} / \mathrm{mL}$, and thus only CS1 activity on NO production can be considered.

In addition to the effect on the NO production, the immunomodulatory potential for the samples was also measured in lymphoproliferation assay using concanavalin A as stimulus for the splenocytes or allogenic stimulation in mixed lymphocyte reaction. CR1 and CR3 had the highest values of lymphocyte proliferation inhibition (up to $100 \%$ ), when assayed at 100 and $33 \mu \mathrm{g} / \mathrm{mL}$ in both assays (Figures $1 \mathrm{c}$ and $1 \mathrm{~d}$ ). Consequently, these samples had the lowest $\mathrm{EC}_{50}$ values for these parameters. These data are relevant if observed that $\mathrm{LC}_{50}$ for them were very superior to these values (Table 2), suggesting an inhibition of proliferation and not toxicity-induced cell death. These data reinforce again the hypothesis of production of bioactive metabolites soluble in chloroform by Cordia rufescens.

$\mathrm{CS} 1, \mathrm{CS} 2$ and CR2, in spite of having the most elevated $\mathrm{EC}_{50}$ values, had not a detectable $\mathrm{LC}_{50}$ or they are superior to $100 \mu \mathrm{g} / \mathrm{mL}$ (Table 2). Two samples had a high percentual of lymphocyte proliferation inhibition with low $\mathrm{EC}_{50}, \mathrm{CR} 1$ and CR3 (Table 2). IL-2, an important cytokine produced upon lymphocyte activation, was also inhibited. Corroborating the immunosuppressive potential of these two samples, both of them had higher values of $\mathrm{LC}_{50}$ when compared with $\mathrm{EC}_{50}$ values obtained. Thus, these results indicate a real effect on inhibition of proliferation and not due cell toxicity.

The results confirm the basis of the utilization of some Cordia species by traditional medicine in pathologies mediated by the immune system. Studies should be continued with the development of more specific assays and in vivo evaluation models for immune-mediated pathologies, followed by fractionation of extracts in order to identify the active compounds.

\section{ACKNOWLEDGMENT}

This work was supported by Millenium Institute of Semi-Arid (MCT), National Council on Scientific and Technological Development (CNPq), FAPESB and FIOCRUZ.

\section{REFERENCES}

Agra MF, França PF, Barbosa-Filho JM 2007. Synopsis of the plants known as medicinal and poisonous in Northeast of Brazil. Rev Bras Farmacogn 17: 114-140.
Al-Awadi FM, Srikumar TS, Anim JT, Path FRC, Khan I 2001. Antiinflammatory effects of Cordia myxa fruit on experimentally induced colitis in rats. Basic Nutritional Investigation 7: 391-396.

Arrebola MRB, Peterlin MF, Bastos DHM, Rodrigues RFO, Carvalho PO 2004. Estudo dos componentes lipídicos das sementes de três espécies do gênero Cordia L. (Boraginaceae). Rev Bras Farmacogn 14: 57-65.

Biavatti MW, Marensi V, Leite SN, Reis A 2007. Ethnopharmacognostic survey on botanical compendia for potential cosmeceutic species from Atlantic Forest. Rev Bras Farmacogn 17: 640-653.

Ding AH, Nathan CF, Stuehr DJ 1988. Release of reactive nitrogen intermediates and reactive oxygen intermediates from mouse peritoneal macrophages. Comparison of activating cytokines and evidence for independent production. J Immunol 141: 2407-2412.

Ficarra R, Ficarra P, Tommasini S, Calabro ML, Ragusa S, Barbera R, Rapisarda A 1995. Leaf extracts of some Cordia species: analgesic and anti-inflammatory activities as well as their chromatographic analysis. Il Farmaco 50: 245-256.

Gottlieb OR, Kaplan MAC, Borin MRMB 1996. Biodiversidade: um enfoque químico-biológico. Rio de Janeiro: Editora UFRJ .

Gottschling M, Miller JS, Weigend M, Hilger HH 2005. Congruence of a phylogeny of Cordiaceae (Boraginales) inferred from ITS1 sequence data with morphology, ecology, and biogeography. Annals of the Missouri Botanical Garden 92: 425-437.

Langstrom E, Chase MW 2002. Tribes of Boraginoideae (Boraginaceae) and placement of Antiphytum, Echiochilon, Ogastemma, and Sericostoma: A phylogenetic analysis based on atpB plastid DNA sequence data. Plant Syst Evol 234: 137-153.

Reddy JS, Rao PR, Reddy MS 2002. Wound healing effects of Heliotropium indicum, Plumbago zeylanicum and Acalypha indica in rats. J Ethnopharmacol 79: 249-251.

Santiago GMP, Viana FA, Pessoa ODL, Santos RP, Pouliquen YBM, Arriaga AMC, Andrade-Neto M, Braz-Filho R 2005. Avaliação da atividade larvicida de saponinas triterpênicas isoladas de Pentaclethra macroloba (Willd.) Kuntze (Fabaceae) e Cordia piauhiensis Fresen (Boraginaceae) sobre Aedes aegypti. Rev Bras Farmacogn 15: 187-190.

Sertié JAA, Basile AC, Panizza S, Oshiro TT, Azzolini CP, Penna SC 1991. Pharmacological assay of Cordia verbenacea III: oral and topical antiinflammatory activity and gastrotoxicity of a crude leaf extract. $J$ Ethnopharmacol 31: 239-247.

Silva SAS, Rodrigues MSL, Agra MF, Cunha EVL, BarbosaFilho JM, Silva MS 2003. Flavonoids from Cordia globosa. Biochem Syst Ecol 32: 359-361.

Silva SAS, Souto AL, Agra MF, Cunha EVL, BarbosaFilho JM, Silva MS, Braz-Filho R 2004. A new arylnaphtalene type lignan from Cordia rufescens A. DC. (Boraginaceae). Arkivoc 6: 54-58.

Stapf MN 2006. Boraginaceae. In: Conceição A, Giulietti AM, de Queiroz LP (eds.) Diversidade e caracterização das fanerógamas no semi-árido. Recife: Associação Plantas do Nordeste, p.73-75.

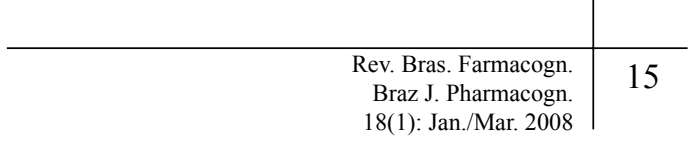

